\title{
Bir Kampüs Açık Mekanının Peyzaj Tasarımı: Süleyman Demirel Üniversitesi Orman Fakültesi Binası
}

\author{
Serap YILMAZ \\ KTÜ Orman Fakültesi, Peyzaj Mimarlığı Bölümü, TRABZON \\ Sorumlu Yazar: serapyilmaz@ktu.edu.tr
}

Geliș Tarihi: 04.06.2015

\begin{abstract}
Özet
Kampüs peyzajı, kentin genel görünümünü etkilediği gibi gençlerin de dört yıl ya da daha fazla süre için yaşam alanıdır. Bu nedenle kampüs dış mekanları binaların dışında kalan boşluklar olarak görülmemeli ve gelişigüzel tasarlanmamalıdır. Aksine kampüs peyzajı; üniversiteli gençleri geleceğe hazırlanmanın ve kariyer gelişiminin getirdiği baskılardan uzaklaştırmalı, zihinsel dinginlik sağlamalı, sosyalleştirmeli, fiziksel aktivite olanağı sağlamalı ve öğrenme çevreleri olarak düşünülmelidir. Bu şekilde tasarlanan kampüs peyzajı eğitim ve öğretimin kalitesini de olumlu olarak etkileyecektir. Bu düşünceler doğrultusunda Süleyman Demirel Üniversitesi Orman Fakültesinin çevresi tasarlanmıştır. Tasarıma başlamadan önce mevcut alanın mekânsal, işlevsel ve doğal peyzaj verileri analiz edilerek, alana ilişkin olumlu-olumsuz nitelikler ve kullanıcı ihtiyaçları ortaya konulmuştur. Orman Fakültesinin çevre tasarımı semantik, sentaktik ve pragmatik açıdan detaylı bir şekilde kurgulanmış ve tasarımın ana fikrini, formal eğitimin dış mekana yansıması oluşturmuştur.

Sonuç olarak yapılan tasarımda okunabilirlik, işlevsellik ve estetiğin yakalanabilmesi için görsel basitlik ve görsel karmaşıklık arasındaki dengenin yakalanması amaçlanmıştır.
\end{abstract}

Anahtar Kelimeler: Peyzaj tasarımı, Kampüs peyzajı, Tasarım süreci

\section{Landscape Design of a Campus Outdoor Spaces: Süleyman Demirel University Faculty of Forestry Building}

\begin{abstract}
As a part of urban scenery, campus landscapes are regarded a living space for students for about four years Therefore campus outdoor areas should not be treated and designed as a left over space of buildings. On the contrary, campus landscapes should be a place for university students to relieve from the stress of concern for the future and career development, as well as a place for mental composure, socialization, physical activity, and learning environment. Campus landscapes designed for these aims will also enhance the quality of education. With these thoughts in mind, the surrounding space of Süleyman Demirel University, Faculty of Forestry was designed. Before the design phase, spatial, functional and natural landscape data of the area were analyzed and, positive and negative qualities, and user needs were determined. Landscape design of the faculty was constructed in detail with regard to semantic, syntactic and pragmatics dimensions and "reflecting formal education to outdoors" became the concept of the design.

In order to provide legibility, functionality and aesthetic quality of the resulting design, a balance between visual simplicity and complexity is concerned.
\end{abstract}

Keywords: Landscape design, Campus landscape, Design process

\section{Giriş}

Kent peyzajının bir parçası olan kampüsler kent siluetini ve yaşamını değiştirdiği gibi birçok üniversiteli için dört yıl ya da daha fazla bir süre, yaşamlarını sürdürdükleri, meslekleriyle ilgili donanımlarını kazandıkları yerler ve günlük deneyim alanlarıdır. $\mathrm{Bu}$ nedenle üniversite kampüsü tasarlanırken aslında gençler için 45 yıllık kullanıma açık bir kent oluşturulmaktadır. Kentler gibi üniversite kampüsleri de çalışma, barınma, dinlenmerekreasyon ve ulaşım işlevlerinin sağlandığı, sosyal iletişimin kurulduğu yerleşmeler olmalıdır (Yıldız ve Şener, 2006). Bir kampüs, sadece yaşayanlarının temel gereksinimlerini karşılayan bir yer değil, onlarda anılar birakan, anlamlar yaratan kendilerini oraya ait hissettikleri yerler olmalıdır (Broussard, 2009; Yalçın, 2012).

Genç insanların perspektifinden kampüse bakıldığında, geniş bir çim yüzeyde yada yapraklı bir ağacın gölgesinde çalışan, dinlenen veya sosyalleşen öğrenciler görülür. Tasarımc1 perspektifinden kampüse bakıldığında formal eğitimin yapılacağ sinifları, laboratuvarları, konferans salonlarını, öğretim üyeleri ve idari personelin odalarını içeren binalar, bu binaların çevresi ve sirkülasyon ağı ile olan 
ilişkisi görülür. Ancak bir kampüse, peyzaj tasarımcısı perspektifinden bakıldığında ise içerdiği dış mekanlar ile dinlendirici ve gençlerin öğrenme sürecini sınıfların dışına taşıyabilecek bir role sahip olduğu görülmektedir ( gençlerin kişisel ve kültürel gelişimi, davranışları, arkadaşlık ilişkileri kurması ve sosyal roller geliştirmesi, toplum olma duygusu, doğa ile kurduğu ilişki vb.).

Kampüs tasarımciları sadece formal eğitim üzerine odaklanmakta, bireyin çevreyi değiştirip kendine göre biçimlendirdiği gibi çevrenin de bireyi değiştireceği gerçeğini unutup, insan-doğa arasındaki ilişkiyi ve fiziksel çevrenin öğrenme üzerindeki etkisini göz ardı etmektedirler. Oysaki iyi tasarlanmış kampüs açık mekanları üniversitelilerin yaşam kalitesini iyileştirecek; doğal elemanlarla olan etkileşim, stres faktörünü azaltarak bireyler üzerinde olumlu zihinsel ve fiziksel etkiler oluşturacaktır. McFarland ve ark. (2008) yaptığı araştırmaya göre kampüs yeşil alanlarını sıklıkla kullanan gençlerin, bu alanları daha az kullananlara göre yaşam kalitesini daha yüksek algıladıkları görülmektedir. Lau ve ark. (2009) ise üniversite kampüslerindeki doğal alanların, insanın zihinsel sağlığı üzerinde olumlu etkiler oluşturan fiziksel çevreler olduğunu vurgular. Bir çok araştırmacı doğal elemanlar içeren peyzajları: bireyler üzerinde duygusal rahatlamayı sağladığı için belirgin bir biçimde iyileştirici mekanlar olarak tanımlanmıştır (Hartig ve ark., 1991; Kaplan ve Kaplan, 1989; Kaplan ve Talbot, 1983; Kaplan, 1995). Bu bağlamda kampüs peyzajının tasarımı hem bir parkta olduğu gibi kullanıcılarına (akademik ve idari personel-ziyaretçi-öğrenci) yeme-içme, okuma, sohbet etme, oturma, müzik dinleme, rehabilite olma, doğa ile temas gibi pek çok etkinliğe imkan verecek yeşil alanlardonatılar içermeli hem de bir kampüsün getirdiği farklı kavramsal ve mekânsal kurguya sahip olmalıdır. Şöyle ki:

1. Kampüs peyzaj1, gençlerin psikososyal yapısının gelişmesi için gerekli olan kazanımları elde edebilmeye yönelik ihtiyaçları ve bunları karşılayan etkinliklerin gerçekleşmesine olanak sağlayan mekansal içeriklere sahip olmalıdır (Düzenli, 2010).
2. Kampüs peyzajı öğrenci çeşitliğini, enerjisini ve doğa merakını yönetmek, stresi azaltmak için mekanlar içermelidir (Schuetz, 2007).

3. Kampüs peyzaj1, gençlerin teoride öğrendiği bilgileri çevrelerinden aldıkları görsel bilgiler ile pekiştirdikleri dış mekan çalışma alanları olarak kurgulanmalıdır.

Özetlenecek olursa kampüs peyzaj1: gençlerin yeni arkadaşlık ilişkileri kurduğu, günlük yorgunluklarından kurtulduğu, sosyal rollerini geliştirdiği, çalışan ve öğrencinin iç içe olduğu tasarlanmış açık mekanlar dizisidir.

Kampüs peyzajının tasarımı şu üç ilkeyi içermelidir (Abu-Ghazzeh, 1999);

- Fiziksel ve ekolojik nitelik: doğal çevre karakterleri (bitkiler, çim yüzeyler, topografya)

- Davranışsal ve fonksiyonel nitelik: insan davranışı ve fiziksel mekanlar arasındaki etkileşimleri (aktivitelerin süresi, sıklığ1, türü; bu aktivitelerin mekanların fiziksel karakterini oluşturması) (Pragmatik/Yararsal Boyut)

- Estetik ve görsel nitelik: görsel tercih, görsel duyumsamayı temel aldığı için dış mekanların ve yapıların estetik bir görünüşe, ortak bir karaktere sahip olması (Sentaktik/Biçimsel boyut)

Kampüs peyzajinda olması gereken etkinlik alanları ise şu şekildedir (Aydın ve Ter, 2008);

- Spor aktivitelerinin yapılacağı alanlar

- $\quad$ Eğitim olanaklı açık hava tartışma alanları (Çalışma/ öğrenme)

- Gezme-dolaşmaya olanak sağlayan alanlar

- Oturmaya olanak sağlayan alanlar (yeme-içme, dinleme, sohbet etme, etrafi ve insanları seyretme )

- Çalışmaya olanak sağlayan sakin alanlar

$\mathrm{Bu}$ düşünceler doğrultusunda, Süleyman Demirel Üniversitesinin (SDÜ) Doğu kampüsünde yer alan Orman Fakültesinin çevresi tasarlanmıştır. $\mathrm{Bu}$ tasarım süreci özellikle gençlerin ihtiyaçları, bu ihtiyaçlara yönelik etkinliklerin ve bu etkinliklerin 
gerçekleșmesine olanak sağlayan mekansal özelliklerin belirlenmesi üzerine odaklanmıştır. Ancak bu süreçte ziyaretçilerin, akademik ve idari personelin ihtiyaçları da göz önünde bulundurulmuştur.

$\mathrm{Bu}$ bağlamda süreç, analiz ve tasarım aşaması ile yürütülmüştür. Analiz aşamasında; mekânsal, işlevsel ve doğal peyzaj verileri değerlendirilmiştir. Tasarım aşaması ise kullanıcı ihtiyaçlarının belirlenmesi ile başlatılmış, belirlenen konsept ve biçim ilişkisi kurularak sonuçlandırılmıştır.

\section{Projenin Gelişimi ve Tasarım Süreci}

Süleyman Demirel Üniversitesi doğu ve batı kampüsü olmak üzere iki kısımdan oluşmaktadır. Proje alanını; SDÜ Doğu kampüsü içinde bulunan ve $30.103 \mathrm{~m}^{2}$ lik bir alanı kapsayan Orman Fakültesi oluşturmaktadır (Şekil 1). Bu alanın 4.092 $\mathrm{m}^{2}$ 'si bina, $2.563 \mathrm{~m}^{2}$ 'si de otopark (96 araçlık) alanı olarak kullanılmaktadır. Binanın çevre düzenleme çalışmasını etkileyecek unsurlar; sirkülasyon aks1, otopark ve ekonomik nedenlerdir. Bu bağlamda çevre düzenleme proje süreci şu şekilde organize edilmiştir:

1. Analiz

2. Tasarım

3. Tasarım ürünü

\section{Analiz}

a. Mekansal analiz

Mekansal analiz ile iç-dış mekan örüntüleri ve kullanımları irdelenerek, aşağıdaki değerlendirmeler yapılmıştır:

- Mevcut yapının dışa açılım noktaları ve kotlarının belirlenmesi

- Mevcut sirkülasyon sisteminin ve otoparkın proje alanı ile olan ilişkisinin belirlenmesi

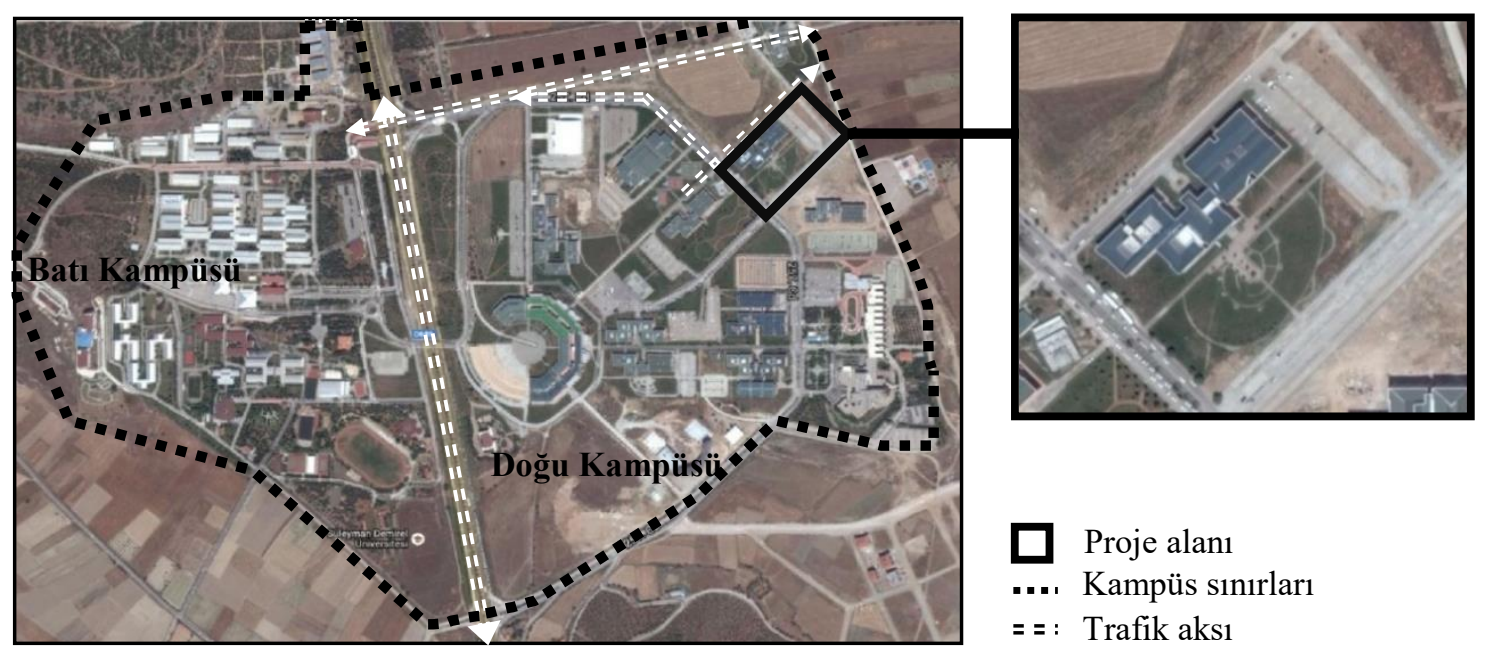

Şekil 1. SDÜ Kampüsü ve proje alanı (URL1, 2015)

b. İșlevsel analiz

İşlevsel analiz, kullanıcının alanda bıraktığ ile biçimlendirilir. Çevrede, "her etkileşim bir iz bırakır" (Sommer ve Sommer, 2002). $\mathrm{Bu}$ düşünce doğrultusunda bireyin alanda bıraktığı izler, bir fiziksel çevrenin gerçekte insanlar tarafından nasıl kullanıldığına ilişkin bir kanıya varılmasını sağlar (Gür, 1996). Dolayısıyla tasarımcı, çevreyi işlevsel açıdan analiz ederken, fiziksel izleri de kullanmalıdır. $\mathrm{Bu}$ bakıș açısıyla, proje sürecinde mevcut durum ve olanaklar analiz edilerek, aşağıdaki değerlendirmeler yapılmıştır:

- Kullanıcıların yürüyüş izlerinin belirlenmesi (Şekil 2) ve

$\bullet$

$$
\text { Kullanıcı ihtiyaçlarının }
$$
belirlenmesi

$\mathrm{Bu}$ değerlendirmeler 1șı ğında alan kullanım kararları alınmıştır (Şekil 3). 


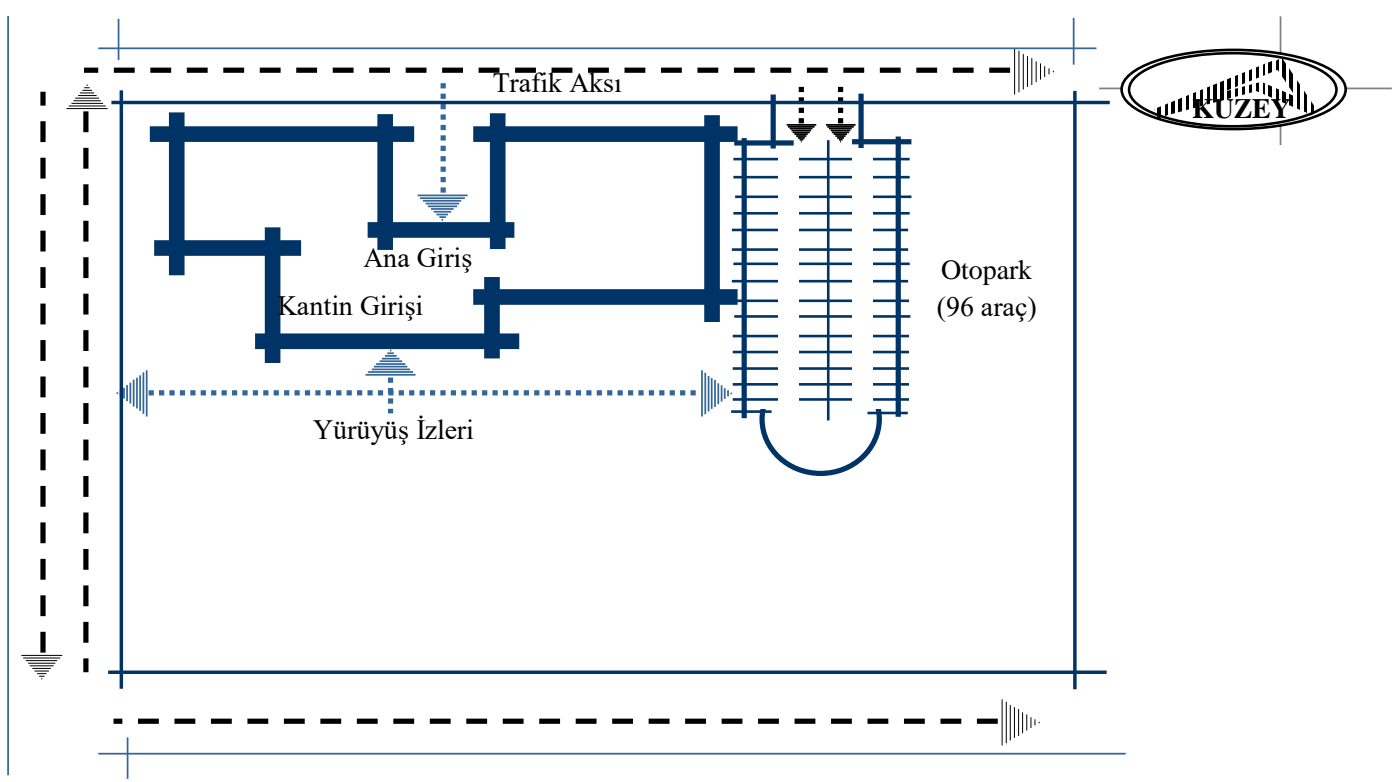

Şekil 2. Yaya izleri ve araç aksları
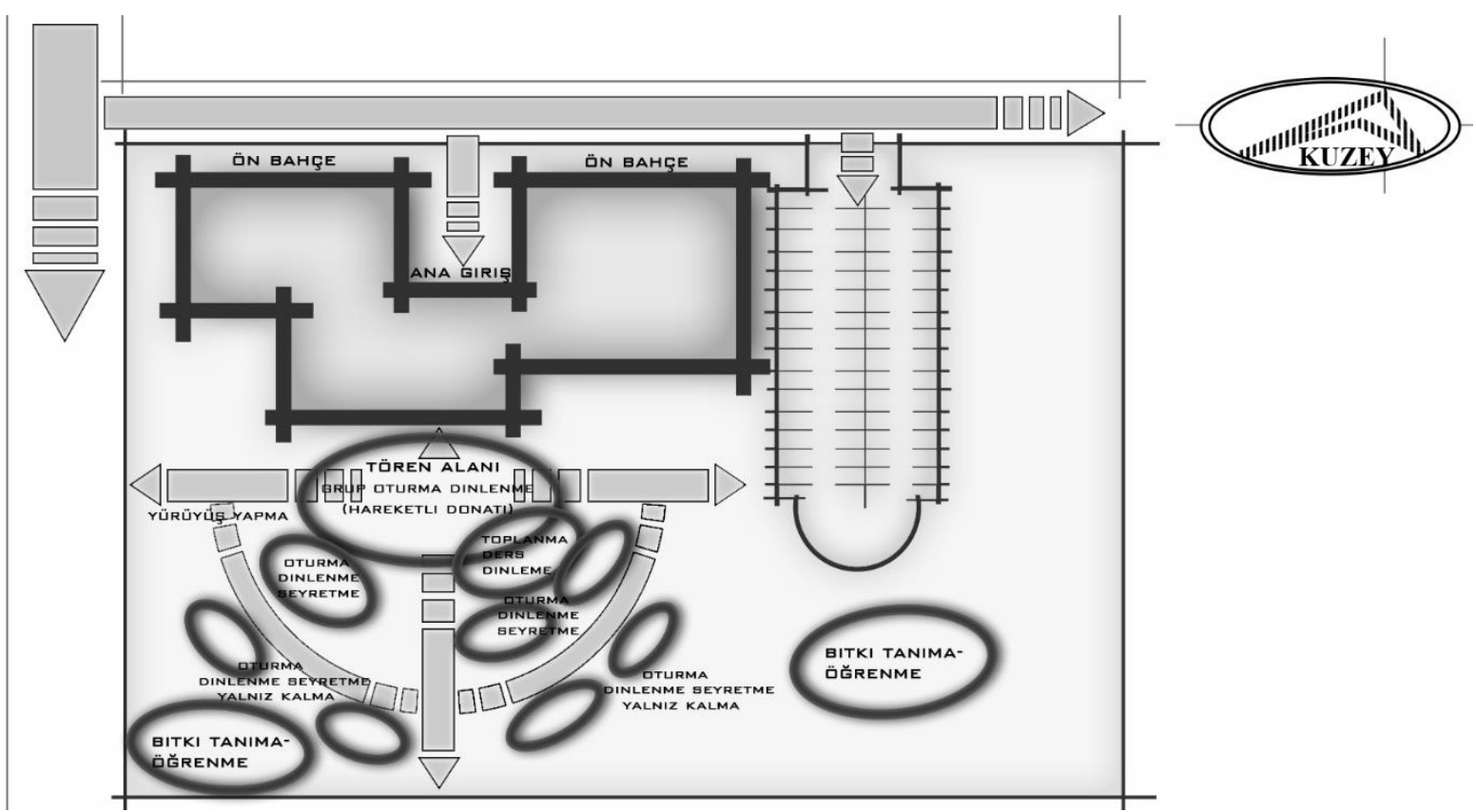

Şekil 3. Alan kullanım kararları

c. Doğal peyzaj verilerin analizi

Doğal verilerin analizi, bitki türü seçimi ve mekan organizasyonu kararları üzerinde etkili olduğu gibi proje alanındaki mevcut bitki türlerinin belirlenmesini ve korunacak bitkilerin ortaya konulmasını sağlar. $\mathrm{Bu}$ durum bitkilendirmeye ve etkinlik alanlarının belirlenmesine ilişkin tasarım kararlarını etkiler. Doğal verilerle ilgili değerlendirmeler Tablo 1 ve Tablo 2'de yapılmıştır:
İklimsel veriler (Rüzgâr, nem, sıcaklık, yağış)

Topografik veriler (Eğim)

Toprak verileri (Toprak türü)

Bitki örtüsü (Ağaç, çalı, yer örtücüler)

İklimsel veriler değerlendirildiğinde, proje alanında don ihtimali yüksek, mevsimler ve gece gündüz arasinda 1s1 değişimi olduğu görülmektedir. Hakim rüzgar yönü güney doğudur. İkinci derecedeki hakim rüzgar yönümüz ise kuzeybatıdır. 
Topografik veriler değerlendirildiğinde, proje alanının eğimi \% 5 'in altındadır. $\mathrm{Bu}$ oran, tasarım kararlarını etkilemeyecek kadar azdir.

Toprak verileri değerlendirildiğinde, proje alanı killi toprak türüne sahiptir.

Bitki örtüsüne ilişkin değerlendirilmeler yapıldığında ise proje alanı içinde peyzaj açısından değerli bitkisel eleman bulunmamaktadır.

$\mathrm{Bu}$ veriler;

- Don ve 1S1 değişimine dayanıklı bitki türlerinin kullanılması,
- Hakim rüzgar yönünde, rüzgara dayanıklı bitkiler ile rüzgarın olumsuz etkisinin azaltılmas1,

- Killi toprakta yetișen bitki türlerinin seçilmesi,

- Güneșli günlerde, gölge olanağ1 sağlayacak bitki türlerinin ve donatıların seçilmesi ve

- Mekanların yöneliminin, rüzgar ve güneş yönüne göre belirlenmesine ilişkin kararlar üzerinde etkili olmuştur.

Tablo 1. Isparta ili aylık maksimum ve ortalama rüzgar yönü ve hızı değerleri (Isparta Meteoroloji Bölge Müdürlügü, 2011).

\begin{tabular}{|c|c|c|c|c|c|c|c|c|c|}
\hline \multicolumn{10}{|c|}{ Aylık Maksimum Rüzgar Yönü ve Hızı (m/sn) } \\
\hline cak & Şubat & Mart & Nisan Mayı & $\begin{array}{c}\text { Haziran Temmu } \\
\mathrm{z}\end{array}$ & $\begin{array}{l}\text { Ağusto } \\
\mathrm{S}\end{array}$ & Eylül & Ekim & Kasım & Aralık \\
\hline & 17.5 & 12.8 & $\begin{array}{l}\text { G. } \\
18.1\end{array}$ & $\begin{array}{ll}\text { K. B. } & \text { G. D. } \\
18.4 & 13.7\end{array}$ & $\begin{array}{l}\text { K. D. } \\
11.9\end{array}$ & 10.9 & $\begin{array}{l}\text { G. D. } \\
15.9\end{array}$ & 12.7 & $\begin{array}{l}\text { G. } \\
13.2\end{array}$ \\
\hline
\end{tabular}

Tablo 2. Isparta ili aylara göre ortalama nem-yağıș-sıcaklık değerleri (Isparta Meteoroloji Bölge Müdürlüğ̈̈, 2011).

\begin{tabular}{|c|c|c|c|c|c|c|c|c|c|c|c|c|}
\hline \multicolumn{13}{|c|}{ Aylık Ortalama Nem (\%) } \\
\hline Ocak & Şubat & Mart & Nisan & Mayıs & Haziran & Temmuz & Ağustos & Eylül & Ekim & Kasim & Aralik & Y1llik Ort. \\
\hline 79 & 76 & 70 & 70 & 68 & 59 & 44 & 40 & 43 & 59 & 55 & 68 & 61 \\
\hline \multicolumn{13}{|c|}{ Aylık Ortalama Yağış (kg/ m²) } \\
\hline Ocak & Şubat & Mart & Nisan & Mayis & Haziran & Temmuz & Ağustos & Eylül & Ekim & Kasım & Aralık & Y1ll1k Ort. \\
\hline 34.9 & 51.8 & 50.4 & 54.7 & 43.1 & 62.0 & 1.8 & 0.6 & 13.2 & 50.4 & 0.2 & 37.0 & 400.1 \\
\hline \multicolumn{13}{|c|}{ Aylık Ortalama Sıcaklık $\left({ }^{\circ} \mathrm{C}\right)$} \\
\hline Ocak & Şubat & Mart & Nisan & Mayıs & Haziran & Temmuz & Ağustos & Eylül & Ekim & Kasim & Aralık & Y1ll1k Ort. \\
\hline 3.0 & 3.7 & 6.4 & 10.2 & 14.1 & 19.5 & 24.7 & 24.0 & 20.0 & 11.3 & 4.2 & 2.5 & 10.8 \\
\hline
\end{tabular}




\section{Tasarım}

Kullanıcı ihtiyaçlarına ilişkin etkinlikler hakkındaki ana kararlar alınarak, tasarım süreci üç aşamada gerçekleştirildi;

- Semantik (Anlamsal) Boyut

- Sentaktik (Biçimsel) Boyut

- Pragmatik (Yararsal) Boyut

\section{Semantik boyut}

Her projenin bir ana fikri olmalıdır düşüncesi ile tasarım süreci başlatılmış ve bu ana fikir, konsepte, konsept de projenin sentaktik ve pragmatik boyutuna şekil vermiştir. Kullanıcılar ve yöneticiler ile yapılan görüşmeler sonucunda proje alanının "açık hava dersliği”" olarak tasarlanmasına karar verilmiş ve konsept olarak "öğrenme kavramı" belirlenmiștir. Konsept, literatürdeki; kullanıcıların dış mekanları öğrenme, keşfetme ve araştırma için kullandıkları (Aydın ve Ter, 2008) bilgisi ile de desteklenmiştir. $\mathrm{Bu}$ bağlamda tasarımcının, dış mekanlardaki aktiviteleri öğrenme olanakları olarak da değerlendirebileceği görülmüştür. $\mathrm{Bu}$ düşünce iç mekanın uzantısı olan bir bahçe tasarlanması fikrini oluşturmuş ve tasarım için benimsenen felsefe doğrultusunda aşağıdaki ilke üzerinde durulmuştur:

- Bireyin görsel olarak edindiği bilgilerin \% 80'i kalıcı olmaktadır. $\mathrm{Bu}$ nedenle öğrenciye, derslerde edindiği bilgileri çevresinde görebilme olanağı sağlandı. Böylece öğrenci teoride öğrendiği konuların uygulamasını, çevresinde görme şans1 bulup, bilgilerini pekiştirebilecektir.

Konsepte ilişkin bu ilke, yapılan sert zemin, alan plastiği ve bitkilendirme tasarımını tesadüfi olmaktan çıkarmıştır. Çevresi ile etkileşime giren öğrencinin çevreden bir takım mesajlar edinmesi için öğrenciye olanaklar sağlanmıştır. Örneğin bir peyzaj mimarlığı öğrencisi çevresine baktığında;

- Hangi bitkiler (renk, doku, biçim yönüyle) yan yana gelebilir?

- Bir yürüyüş aksı nasıl vurgulanır?

- Bitki, alan plastiği ve sert zeminle mekan nasil tanımlanır?

- Mekanlar arası bağ nasıl kurulur?
- Mekan bileşenleri (bordür, oturma basamakları vb.) nelerdir ve nas1 kullanilır?

- Donatılar nerede ve nasil kullanılır?

- Acer palmatum'un yaprakları nasıldır?

- Betula alba'nın gövdesi ne renktir?

- Sophora japonica nasıl bir kaligrafik özellik gösterir? Sorularına,

Bir orman- orman endüstri mühendisliği öğrencisi çevresine baktığında;

- Hangi bitkinin gövdesi nasıl biçimleniyor?

- Hangi bitkinin dallanışı nasıldır?

- Hangi bitkinin yapraklarının dizilimi, biçimi nasıldır?

- Cedrus libani'nin kozalak yapısı nasıldır?

- Bölgede var olan bitkiler hangileridir? Sorularına yanıt bulmalıdır.

\section{Sentaktik boyut}

Biçimsel yaklaşımı çalışma alanına konu olan Orman Fakültesi'nin resmi bir kurum olması ve Orman Fakültesinin ana içeriği (ekoloji, doğallık, doğal kaynaklar, sürdürülebilirlik vb.) belirlemiștir. Dik açılı çizgiler; resmi bir kurumu, eğri çizgiler ise doğallığı temsil etmiştir. Binanın yakın çevresinde dik açılı çizgiler, binadan uzaklaştıkça eğri çizgilere dönüşerek daha doğal-doğayı taklit eden bir tasarım yaklaşımı benimsenmiştir. Projenin biçimsel analizi Şekil 4’te gösterilmiştir:

\section{Pragmatik boyut}

Tasarımc1, mekanları tasarlarken kullanıcı ihtiyaçlarını anlamayı amaçlamalıdır. Çünkü bir mekana gerçek değerini kazandıran, kullanıcıların yaşantılarını en doğru biçimde yansitabilmesidir. Ancak bu şekilde yaşayan ve yaşanabilen mekanlar tasarlanabilir. İnsanın amacına bağlı olarak bir mekanda, bir etkinliği gerçekleștirmesi için mekanın bu etkinliğe uygun olması gereklidir. $\mathrm{Bu}$ da ancak iyi bir mekan organizasyonu ile mümkün olabilir. Bu nedenle tasarımın sonuç ürününün kullanıcı ihtiyaçlarını karşılaması için ihtiyaç-etkinlik-mekan ilişkisi iyi kurulmalıdır.

Proje kapsamında literatürden ve kullanicidan elde edinilen bilgiler doğrultusunda ihtiyaç-etkinlik-mekan ilişkisi Tablo 3'de ortaya konulmuştur; 


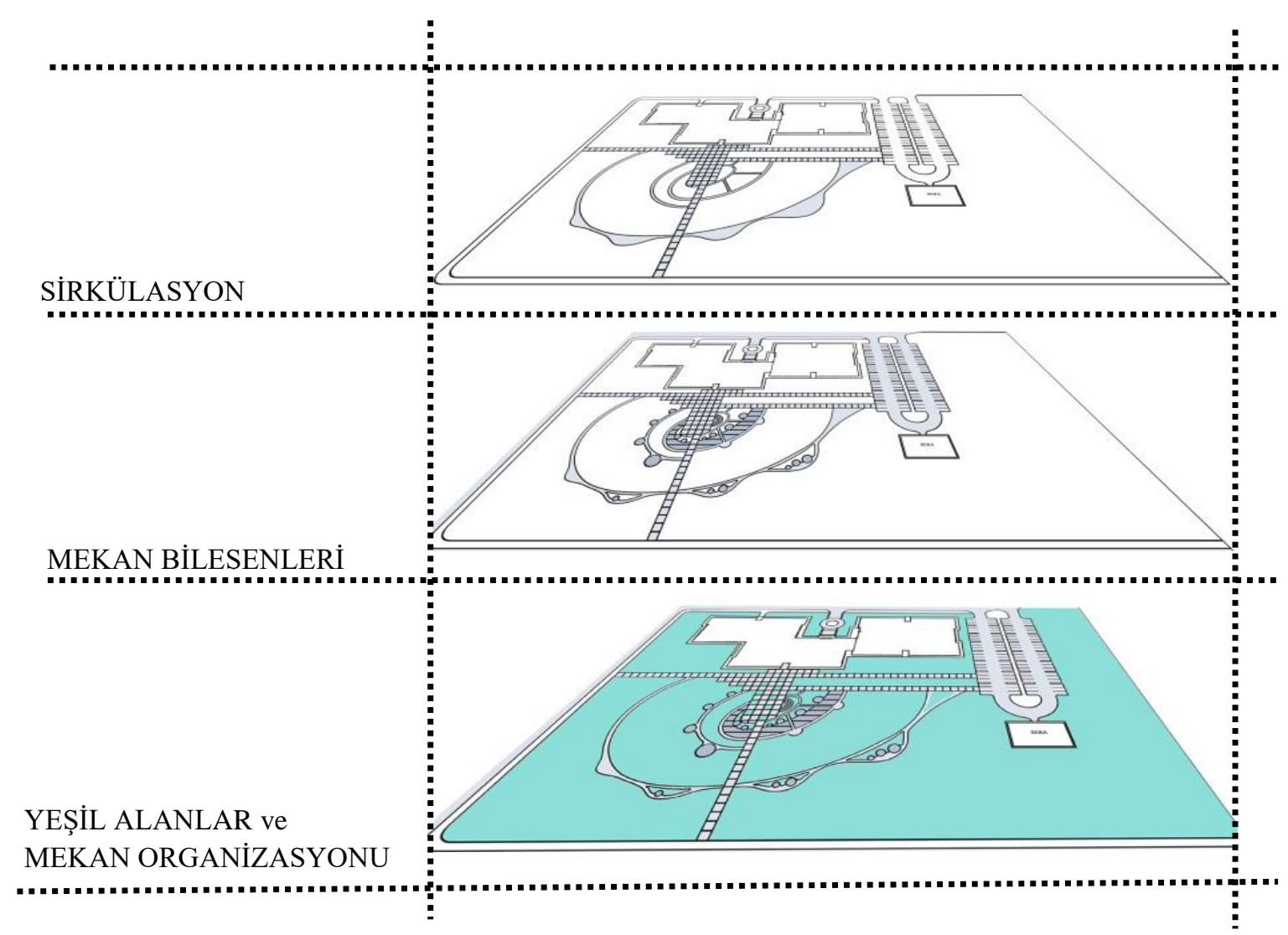

Şekil 4. Projenin biçimsel analizi

Tablo 3. İhtiyaç-etkinlik-mekan ilişkisi

\begin{tabular}{|c|c|c|c|}
\hline & İHTIYAÇ & ETKINNLIK & MEKAN \\
\hline 1.Eğitim & $\begin{array}{l}\text { - Doğayı tanımak-korumak } \\
\text { - Doğa ile iç içe olmak } \\
\text { - Bitkileri tanımak } \\
\text { - Peyzajı tanımak } \\
\text { - Gözlem yapmak } \\
\text { - Bilgi edinmek } \\
\text { - Bilgiyi paylaşmak }\end{array}$ & $\begin{array}{l}\text { - Bitkiler arasında gezinti } \\
\text { - Bitkiler ve peyzaj hakkında } \\
\text { bilgilendirme ve sunumlar } \\
\text { - Doğa ve doğa koruma hakkında } \\
\text { bilgilendirme ve sunumlar }\end{array}$ & $\begin{array}{l}\text { - Gezinti yolları } \\
\text { - Oturma basamakları } \\
\text { - Seyir alanları } \\
\text { - Bitkilendirilmiş alanlar } \\
\text { - Toplanma alanı }\end{array}$ \\
\hline 2.Sosyalleşme & $\begin{array}{l}\text { - Eğlenmek } \\
\text { - Yeni insanlarla tanışmak } \\
\text { - Arkadaşları ile birlikte olmak } \\
\text { - Sohbet etmek }\end{array}$ & $\begin{array}{l}\text { - Konuşma } \\
\text { - Selamlaşma } \\
\text { - Gösteri (müzik, dans) izlemek } \\
\text { - Oturma } \\
\end{array}$ & $\begin{array}{ll}\text { - Oturma alanları } \\
\text { - Oturma basamakları } \\
\text { - Yürüyüşalanları } \\
\text { - Toplanma alanı } \\
\end{array}$ \\
\hline $\begin{array}{l}\text { 3. Temel } \\
\text { İhtiyaçlar }\end{array}$ & $\begin{array}{l}\text { - Beslenmek } \\
\text { - Dinlenmek } \\
\text { - Güvende hissetmek } \\
\text { - Yalnız kalmak } \\
\text { - Ait olduğu bir yerde olmak }\end{array}$ & $\begin{array}{l}\text { - Yeme-içme } \\
\text { - Oturma } \\
\text { - Güneşlenme } \\
\text { - Gölgelenme } \\
\text { - Arkadaşlarıyla zaman geçirme } \\
\text { ve sohbet etme } \\
\text { - Çevredekilerden uzaklaşma } \\
\text { - Anma-kutlama yapma }\end{array}$ & $\begin{array}{ll}\text { - } & \text { Yeme-içme alanı } \\
\text { - } & \text { Oturma alanları } \\
\text { - } & \text { Çim yüzeyler } \\
\text { - } & \text { Töreç altı alanı oturma alanları }\end{array}$ \\
\hline
\end{tabular}

\section{Tasarım Ürünü}

Kampüsün bir bölümünü oluşturan proje alanı gençlere yönelik, öğrenim odaklı bir açık mekan olarak tasarlanmıştır. Tasarımcı bu açık mekanda gençlerin sosyalleşmesi, dinlenmesi, derslerin ve günlük hayatın stresinden uzaklaşmalarına yönelik ihtiyaçlarını daha iyi karşılayabilmeleri için alt mekanlar tasarlamış ve ana kurguyu formal eğitimin dış mekana yansıması üzerine oluşturmuştur. $\mathrm{Bu}$ düşünce doğrultusunda diş mekanda kullanılan bitkiler, mekan bileşenleri 
gençlerin teoride öğrendiklerini pratikte görmelerini sağlayacak birer obje olarak değerlendirilmiş ve "öğrenme kavramı" konsepti proje sürecinin her adımında belirleyici olarak, projenin semantik, sentaktik ve pragmatik boyutuna biçim vermiştir. $\mathrm{Bu}$ doğrultuda bitkilendirme-arazi formu-sert zemin tasarımı projenin semantik, sentaktik ve pragmatik içeriğini destekleyecek biçimde tasarlanmıştır (Tablo 4). Tasarımın sonuç ürününde ise konsept, işlev ve estetik arasındaki ilișiler net olarak ortaya konularak, estetik, okunabilir ve yaşayan bir kampüs açık mekanı tasarlanmıştır (Şekil 5) ve tasarımla ilgili aşağıdaki kararlar alınmıştır (Şekil 6);

- Fakülte binasının ana girişinin yer aldığ 1 ön bahçe, karşılama alanı olarak tasarlanmış ve bitkilerle vurgulanmıştır (Magnolia grandiflora, Acer palmatum "Atropurpurea", Juniperus comminus " Hibernica" vb.).

- Fakülte binasının arka bahçeye açılan kantin k1smı ise ana etkinliklerin gerçekleștirildiği mekanlar olarak değerlendirilmiştir. Burada kullanıcılara dinlenme-oturma-seyretme, aktif bir biçimde hareket etme olanakları sağlanırken, çim yüzeylerin, bitkilerin ve alan plastiğinin sağladığı doğallıkla iç içe olmaları da düşünülerek tasarım biçimlendirilmiştir.

- Tasarlanan açık mekanlarda, kullanıcıların gruplaşma ihtiyacı göz önünde bulundurularak donatılar (sabit ve hareketli oturma elemanları) yerleştirilmiştir. Hareketli donatılar ile bazı mekanların zaman zaman işlev değişimi sağlanmıştır (oturma alanının tören alanına dönüştürülmesi gibi).

- Donatılar ve mekânsal bileşenler (oturma basamakları, alan plastiğinin oluşturduğu tepecikler, çim yüzeyler, bordürler ) oturma, uzanma, gruplar halinde sohbet etme, ders dinleme gibi etkinlikleri destekleyecek șekilde tasarlanmıștır.

- Fakülte çevresi, mümkün olabildiğince çeşitli bitki türü kullanılarak bitki tanıma derslerinin uygulama alanı olarak tasarlanmıştır. Ancak bu yoğun bitki kullanımının mekanın okunabilirliğini bozmaması için ana aksların (Betula alba, Lagerstroemia indica, Prunus cerasifera, Malus floribunda) ve mevcut otoparkın (Tilia tomentosa) aynı bitkilerle vurgulanacağı bir tasarım anlayışı benimsenmiştir.

- Fakülte çevresinin kış aylarında da bitkilerin sağladı $\breve{g}$ yeşil ve estetikten yoksun kalmaması için bitkilendirme tasarımında herdem yeşil bitkiler (Cedrus sp., Abies sp., Picea sp., Pittosporum sp. vb.) ve kaligrafik bitkiler (Lagerstroemia indica, Sophora japonica "Pendula" vb.) kullanılmıștır

Tablo 4. Bitkilendirme-arazi formu-sert zemin tasarımı projenin semantik, sentaktik ve pragmatik boyutu

\begin{tabular}{|c|c|c|c|}
\hline & $\begin{array}{c}\text { Semantik } \\
\text { Boyut }\end{array}$ & Sentaktik Boyut & Pragmatik Boyut \\
\hline $\begin{array}{l}\text { 1. Bitkilendirme } \\
\text { Tasarımı }\end{array}$ & 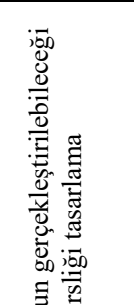 & $\begin{array}{l}\text { - Sinırları tanımlama } \\
\text { - Yürüyüş akslarının tanımlama } \\
\text { - Mekan oluşturma ve tanımlama } \\
\text { - Mekanları birbirinden ayırarak ya da } \\
\text { çevreleyerek, bu mekanlara kimlik } \\
\text { kazandırma }\end{array}$ & $\begin{array}{l}\text { - Yönlendirme } \\
\text { - Oluşturulan vistalarla manzara seyretme } \\
\text { - Peyzajın dört mevsim renkli kalmasının } \\
\text { sağlanması ile işlevsel ve görsel olarak } \\
\text { kullanımda süreklilik oluşturma } \\
\text { - Karışıklık oluşturmayacak şekilde, bitki } \\
\text { çeşitliliğini sağlama ve endemik bitkiler } \\
\text { kullanma } \\
\text { - Bitkileri tanıma }\end{array}$ \\
\hline $\begin{array}{l}\text { 2. Arazi Formu } \\
\text { Tasarımı }\end{array}$ & 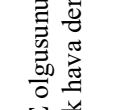 & $\begin{array}{ll}\text { - } & \text { Sinırları tanımlama } \\
\text { - } & \text { Mekan oluşturma } \\
\text { - } & \text { Mekanları birbirinden ayırma } \\
\end{array}$ & $\begin{array}{ll} & \text { Yönlendirme } \\
\text { - } & \text { Mahremiyet hissi sağlama } \\
\text { - } & \text { Güvende hissetme } \\
\end{array}$ \\
\hline $\begin{array}{l}\text { 3. Sert Zemin } \\
\text { Tasarımı }\end{array}$ & 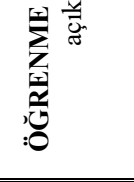 & $\begin{array}{l}\text { - } \quad \text { Yürüyüş akslarının tanımlama } \\
\text { - } \quad \text { Mekanlar arasında bağ kurma } \\
\text { - Farklı işlevleri olan mekanları } \\
\text { tanımlama ve sınırlandırma }\end{array}$ & $\begin{array}{l}\text { - Yönlendirme } \\
\text { - Yalnız kalma } \\
\text { - Grup paylaşımları } \\
\text { - Topluca gösteri-sunum-ders dinleme } \\
\text { - Tören yapma }\end{array}$ \\
\hline
\end{tabular}



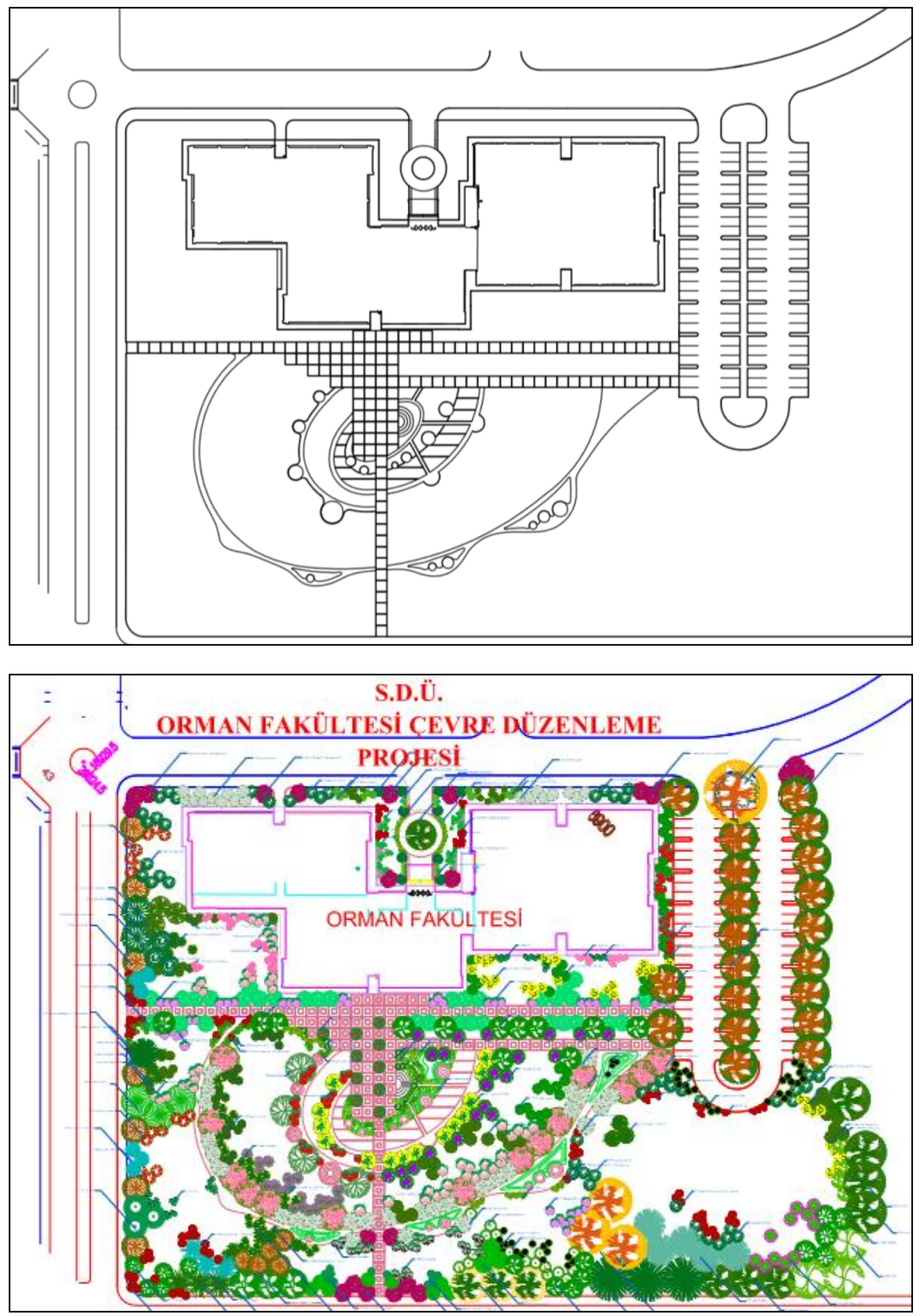

Şekil 5. S.D.Ü. Orman Fakültesi Çevre Düzenleme Projesi sert zemin-yumuşak zemin ve bitkilendirme tasarımı 

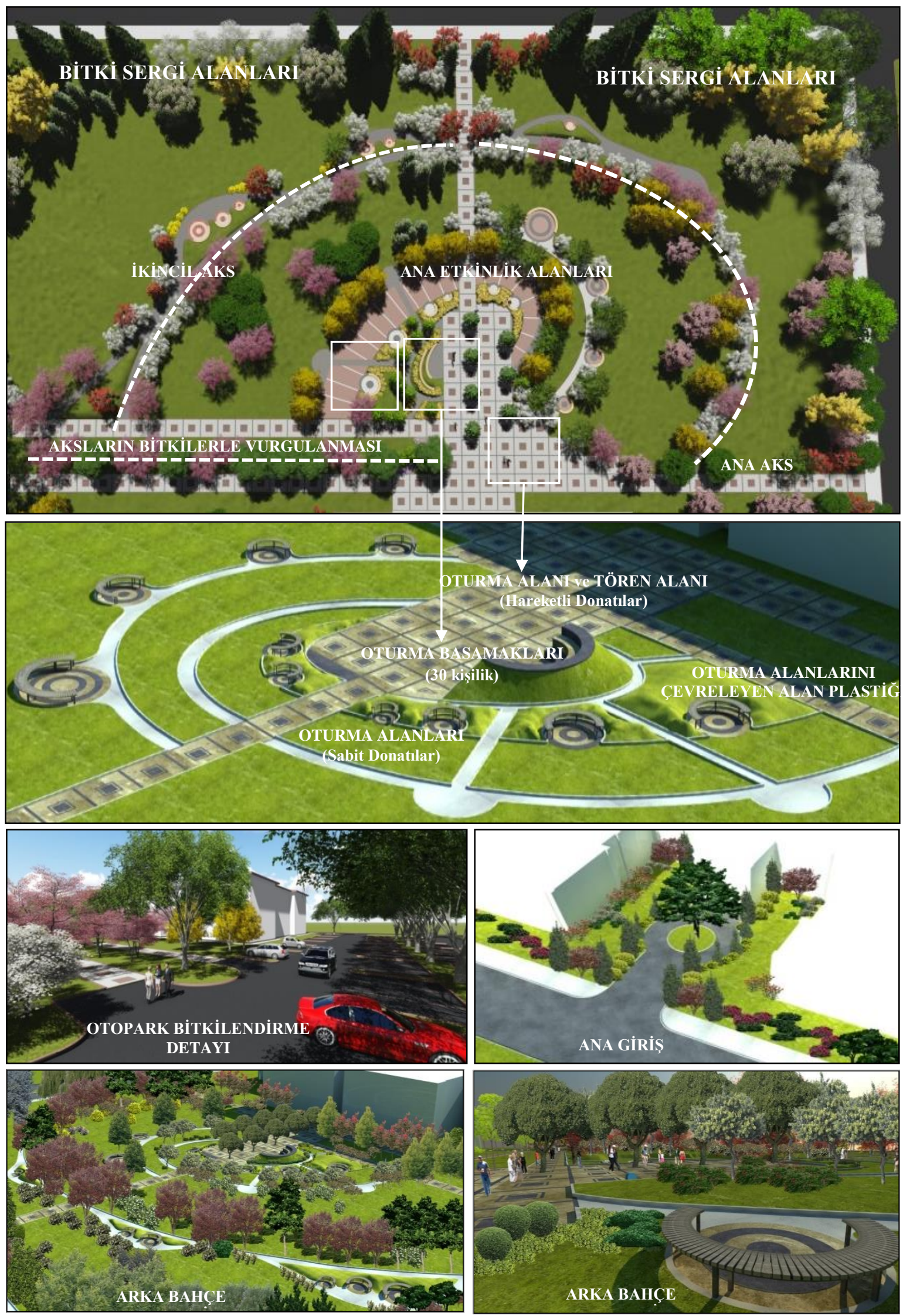

Şekil 6. Proje tasarımının detaylar Sonuç 
SDÜ Orman Fakültesi için tasarlanan projenin sert-yumuşak zemin uygulaması oturma basamakları ve yapay tepecikler dışında üniversitenin imkanları dahilinde ve bir peyzaj mimarı kontrolünde yapılırken, bitkilendirme uygulamas1 ise Peyzaj Mimarlığı ve Orman Mühendisliği bölümleri öğretim üyelerinin kontrolünde yapılmıştır.

Bitkiler tasarlanan ölçülere ve çeşitliliğe ulaştığında ve donatılar mekanlardaki yerini aldığında tasarlanan proje daha renklenecek, canlanacak ve yaşar hale gelecektir. Proje alanında ön görülen sirkülasyon, oturmadinlenme alanları ve geniş çim yüzeyler ile gençlerin rahat bir ortamda doğa ile içiçe eğitim görmelerinin sağlanacağ düşünülmektedir.

$\mathrm{Bu}$ projenin SDÜ kampüsünde hayat bulması ve gençler tarafindan kullanıyor olması tasarımcının verdiği kararların ne derece isabetli olduğunu denetlemek ve kullanıcı memnuniyetini değerlendirmek için bir firsat olușturmuștur. Tasarlanmıș bir alan kullanıcısı olmadan bir anlam taşımayacağı için bu alan hakkındaki en doğru bilgiler ancak kullanıcılardan elde edilir. Bu nedenle "kullanım sonrası değerlendirme" yöntemi ile bu alanı kullananların düşünceleri alınarak, uygulamada bir takım eklemeler ve çıkarmalar yapılabilir. $\mathrm{Bu}$ değerlendirmeden elde edilen bulgular, sonraki kampüs tasarımlarında yol gösterici de olabilir. Böylece kampüslerdeki dış mekânlar "artık mekanlar" olarak değerlendirilmeden girişler, toplanma, dinlenme ve dış mekan çalışma alanları olarak kurgulanması sağlanabilir.

\section{Kaynaklar}

Abu-Ghazzeh T. M. 1999. Communicating behavioral research to campus design factors affecting the perception and use of outdoor spaces at The University of Jordan. Environment and Behavior, 31 (6), 764-804.

Aydın D., Ter U. 2008. Outdoor space quality: case study of a university campus plaza. International Journal of Architectural Research, 2 (3), 189-203.

Broussard, E. 2009. The power of place on campus. Chronicle of Higher Education 55 (34), 12-13.

Gür ö. Ş. 1996. Mekan Örgütlenmesi. ISBN:975-94906-0-9, 280s, Gür yayınc1lik, Trabzon.
Düzenli T. 2010. Kampüs açık mekan olanaklarının gençlerin psikososyal yapısına bağlı olarak incelenmesi: K.T.Ü. Kanuni kampüsü örneği. Doktora Tezi, K.T.Ü. Fen Bilimleri Enstitüsü, 182 s. Trabzon.

Hartig, T., Mang, M., ve Evans, G.W. 1991. Restorative effects of natural environment experience. Environment and Behavior, 23 (1), 326.

Kaplan, S. 1995. The restorative benefits of nature:towardan integrative framework. Journal of Environmental Psychology, 15, 169-182.

Kaplan, R. ve Kaplan, S.1989. The experience of nature: a psychological perspective. ISBN:0521-34939-7, 342s, Cambridge University Press. New York.

Kaplan, S. ve Talbot, J.F., 1983. Psychological benefits of a wilderness experience, Chapter 5, ( Eds: Altman, I. and Wohlwill, J.F., Behavior and the Natural Environment ) Springer US, ISBN: 978-1-46133541-2, 163-203, New York.

Lau S. S. Y., Gou Z., Liu Y. 2009. Introducing Healing Gardens into a Compact University Campus: Design Natural Space to Create Healthy and Sustainable Campuses. Landscape Research, 34 (1) 55-81.

McFarland, A.L. Waliczek, T.M. and Zajicek, J.M. 2008. The relationship between student use of campus green spaces and perceptions of quality of life. HortTechnology, 18(2) 232-238.

Schuetz P. G. 2007. Influences of Campus Environment on Adult Community College Student Engagement, Doctor of Philosophy in Education, University of Calıfornia, 240s. Los Angeles.

Sommer R., Sommer B. 2002. A Pratical Guide to Behavioral Research: Tools and Techniques. ISBN: 0-19-514209-8 Oxford university press, New York. 380s.

Yalçın, A. E. 2012. Yer duygusu ve peyzaj değerleri arasındaki ilişkinin kampüsler üzerinde değerlendirilmesi, Yüksek Lisans Tezi, Ankara Üniversitesi Fen Bilimleri Enstitüsü, 139 s. Ankara.

Yıldız D. ve Sener, H. 2006. Binalarla tanımlı dış mekanların kullanım değeri analiz modeli. İTÜ Dergisi/A Mimarlık, Planlama, Tasarım, 5, (1), 115-127.

URL1- www.google.com/maps, 2015 